\title{
Small Hive Beetle, Aethina tumida (Murray) 1
}

Malcolm T. Sanford ${ }^{2}$

\section{Introduction}

The small hive beetle (Aethina tumida) is native to South Africa. The name differentiates it from the larger hive beetle also found in South Africa, Hyplostoma fuligineus. Both inhabit almost all colonies of honey bees (Apis sp.) in South Africa, but are generally not considered significant problems. In 1998, the small hive beetle was discovered in Florida and identfied by Dr. Michael Thomas of the Florida Department of Agriculture and Consumer Services. Prior to identification in Florida, the beetle merited only a paragraph in most books on honey bee pests and predators.

\section{Distribution}

Although not fully documented, it is thought the beetle may be found in any subtropical and tropical parts of Africa. Anecdotal reports subsequent to discovery in the New World indicate it may also inhabit more temperate areas.

As of June 1999, the beetle has been found in Georgia, North and South Carolina, Florida, Minnesota, Ohio, Pennsylvania and New Jersey in the United States. Although first described in Florida, it is thought the beetle was originally introduced in the coastal portions of South Carolina or Georgia and then transported in bee colonies to Florida.

Introduction into other states has principally been through package bees from South Carolina and Georgia. Whether the beetle can persist in temperate regions of the United States and how far it will spread is only conjecture at the present time.

\section{Description and Life Cycle}

The small hive beetle undergoes complete metamorphosis, passing through the egg, larva, pupa, and adult stages. Only one concentrated study has been conducted on this creature by A.E. Lundie in 1940. Most of the life cycle information comes from his study.

\section{Eggs}

Eggs of Aethina tumida are pearly-white, 1.4 m.m. long by $0.26 \mathrm{~m} . \mathrm{m}$. wide, similar in appearance to honey bee eggs, but smaller, being approximately two-thirds the length of the latter. Eggs are deposited in irregular masses. The female appears to prefer some crevice or cavity. Comb is not required and often ignored when females lay eggs as they can be

1. This document is EENY-094, one of a series of Featured Creatures from the Entomology and Nematology Department, Florida Cooperative Extension Service, Institute of Food and Agricultural Sciences, University of Florida. Published: June 1999. This document is also available on Featured Creatures Website at http://creatures.ifas.ufl.edu. Please visit the EDIS Website at http://edis.ifas.ufl.edu. Additional information on these organisms, including many color photographs, is available at the Entomology and Nematology Department WWW site at http://entnemdept.ifas.ufl.edu/.

2. Malcolm T. Sanford, professor, Entomology and Nematology Department, Cooperative Extension Service, Institute of Food and Agricultural Sciences, University of Florida, Gainesville, FL 32611.

The Institute of Food and Agricultural Sciences (IFAS) is an Equal Employment Opportunity - Affirmative Action Employer authorized to provide research, educational information and other services only to individuals and institutions that function without regard to race, creed, color, religion, age, disability, sex, sexual orientation, marital status, national origin, political opinions or affiliations. For information on obtaining other extension publications, contact your county Cooperative Extension Service office. Florida Cooperative Extension Service / Institute of Food and Agricultural Sciences / University of Florida / Larry R. Arrington, Interim Dean 
found anywhere within the hive. Incubation period varies from one to six days, with most hatching between two to four days. The number of eggs a single female can lay has not been determined, however, Lundie has shown that two or three beetles in a pile of supers can cause a heavy infestation. Females are also relatively long-lived (ranging from a few days to several months) which adds to their egg-laying capacity.

\section{Larvae}

The larva of the small hive beetle is the damaging stage of this pest. Larvae emerge from the egg shell through a longitudinal slit. Newly-emerged larvae have relatively large heads and numerous protuberances all over their bodies. This may protect them from being smothered in honey. Beetle larvae may be confused with those of the greater wax moth Galleria melonella), however, they can easily be distinguished by the presence of six prominent anterior legs. Wax moth larvae have a number of smaller less-developed, uniform prolegs. Both organisms may be found simultaneously in the same colony.

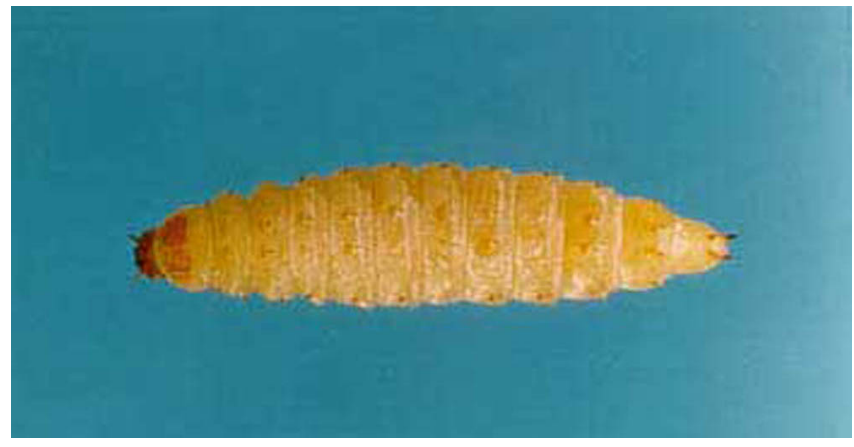

Figure 1. Small hive beetle larva, Aethina tumida (Murray). Credits: Divsion of Plant Industry

There is great variation in growth rate of same-aged larvae Generally it is 10 to 14 days, but may be a week or longer. Slower maturing larvae are smaller and give rise to small adults. Many die soon after pupation, whereas mortality is less in quicker maturing individuals. Larvae grow to $3 / 16$ to $1 / 4$ inch by day four, reaching $7 / 16$ inch with a $1 / 16$ inch diameter when full grown. Larvae entering the soil make a smooth-walled earthen cell to pupate. In damp soil, these may be connected by a tunnel to the surface and larvae may return to the surface before pupating. It is during transition from larva to pupa that the insect is vulnerable. The nature of the soil is also thought to be a variable in successful development.

\section{Pupae}

Pearly white color predominates in newly formed pupae. Pigmentation begins with transformation to adult, first in the eyes and then wing base before encompassing the whole body. Frequent twitching of legs is observed as maturing occurs within the pupal skin. Period spent in the soil varies greatly from 15 to 60 days. The majority of beetles emerge after three to four weeks in the ground.

\section{Adults}

The newly-matured adult is light, yellowish brown and becomes brown, dark brown and finally black at full maturity. This changes take place during pupation and brown or black adults may be seen emerging from the ground. During the first day or two after emergence, young beetles are active, take flight readily and orient toward light. Later they become less active and keep to less illuminated portions of the bee colony. Adults are covered with fine hair, which makes them difficult to pick up by hand.

Females begin to lay eggs about a week after emergence. Adults show great size variablility, but most are approximately $3 / 16$ inch long and $2 / 3$ broad as long. They are about one-third the size of a honey bee worker.Longevity appears to be evenly distributed across ages, ranging from only a few days to six months. Forty of sixty-eight individuals in Dr. Lundie's study lived over two months. Longevity and overlapping of generations makes the beetle a constant source of annoyance to beekeepers.

\section{Economic Significance}

The small hive beetle is not considered a major problem in South Africa. However, coincidentally with detection in the United States, a large number of colony deaths have been reported by U.S. beekeepers. Certainly the beetle puts more stress on a colony and can be a final straw in survival when its effects are multiplied by those of varroa mites and other maladies. Some colonies have been reported to 


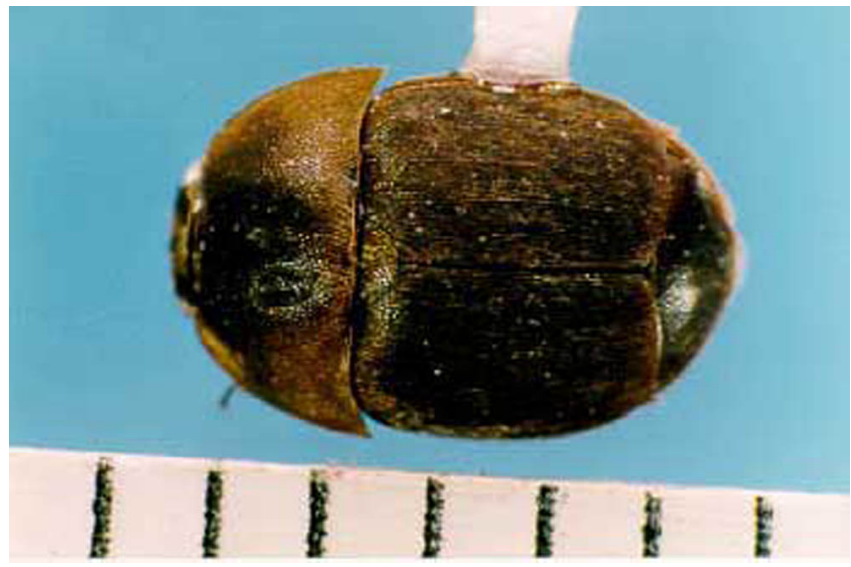

Figure 2. Dorsal view of small hive beetle, Aethina tumida (Murray). Credits: Divsion of Plant Industry

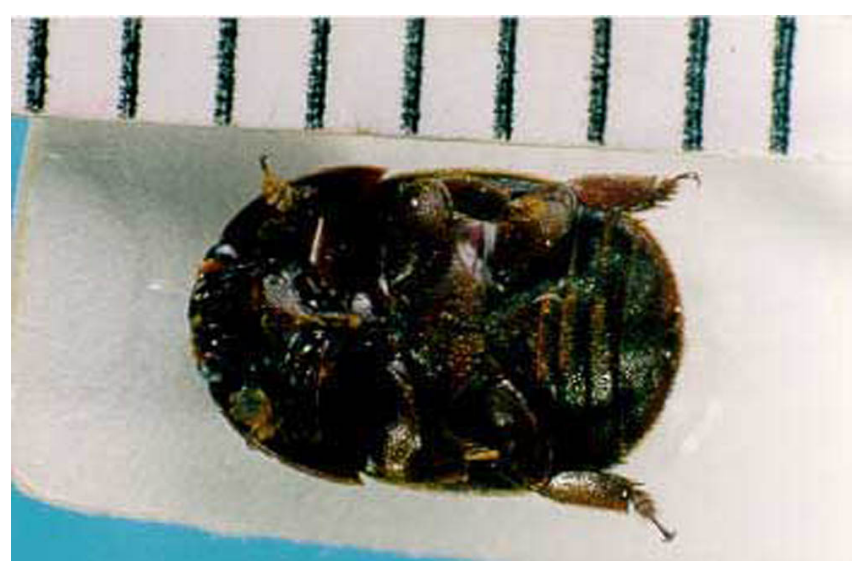

Figure 3. Ventral view of small hive beetle, Aethina tumida (Murray). Credits: Divsion of Plant Industry

collapse after beekeepers have united them with other highly-infested supers, a common strategy for controlling wax moth infestation. The major economic damage, however, appears to be done by larvae found in unprotected honey supers, Like that of the wax moth, the beetle larva is a scavenger. Any situation that reduces the bee population may enable these organisms to get a significant foothold in a colony. Although wax moth larvae eat comb enriched by honey bee pupal skins, beetle larvae eat live brood and honey. Worse, they defecate in the honey promoting fermentation. Fermenting odor may be the first sign of a beetle-infestation. Fermentation is associated with many of the beetles in the family Nitidulidae. Frothy, fermented honey produced by the larvae is abandoned by the bees. Infestation of honey filled supers can happen very quickly. It appears beetles may lay eggs when supers are removed. Thus, larvae can hatch when no adult honey bees are present. Largest infestations have been found in and

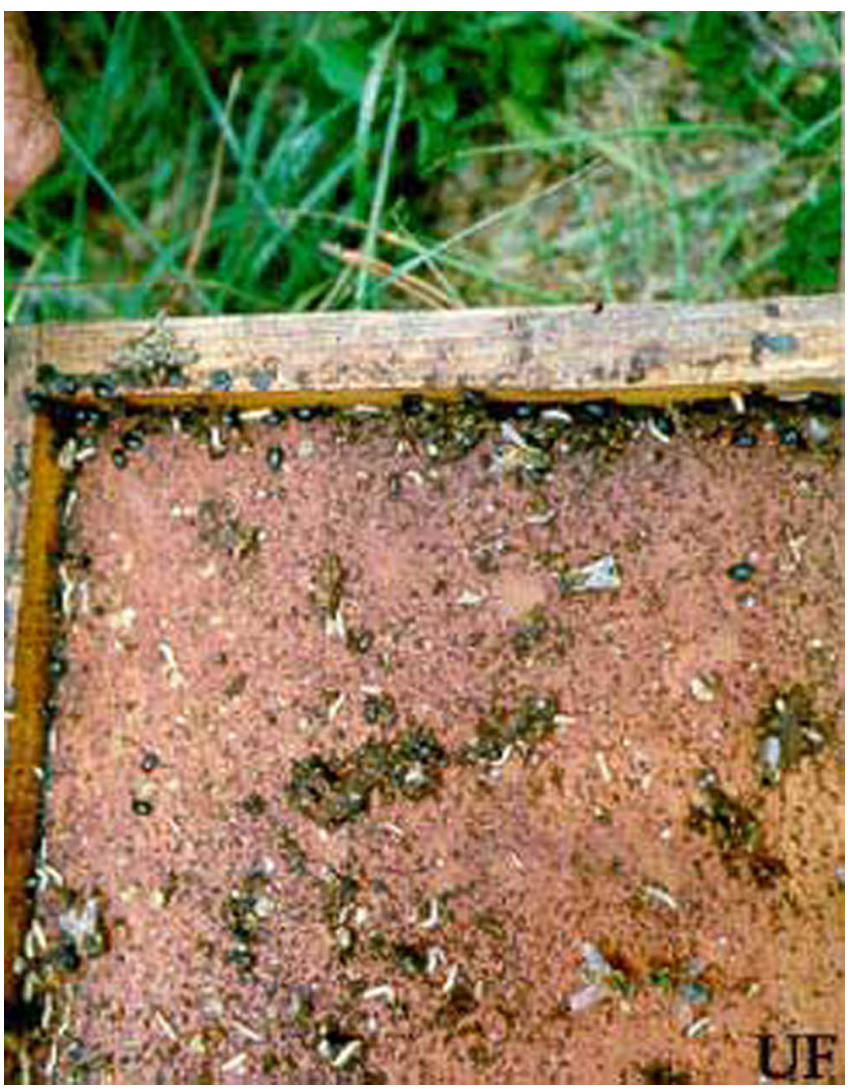

Figure 4. Small hive beetle larvae, Aethina tumida (Murray), with adults and worker bees on bottom board. Credits: M.T. Sanford, University of Florida

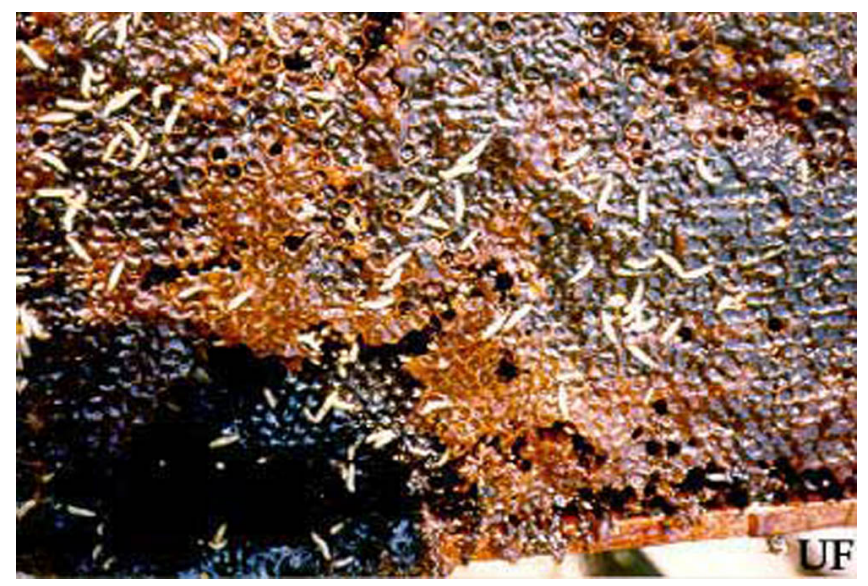

Figure 5. Beetle larvae, Aethina tumida (Murray), on capped honey. Credits: M.T. Sanford, University of Florida

near honey houses. Unlike wax moth larvae, those of the small hive beetle do not appear to destroy the comb. Thus, fermented honey can be washed off infested combs, particularly those reinforced by generations of pupal honey bee skins, and they will be reused by bees. 


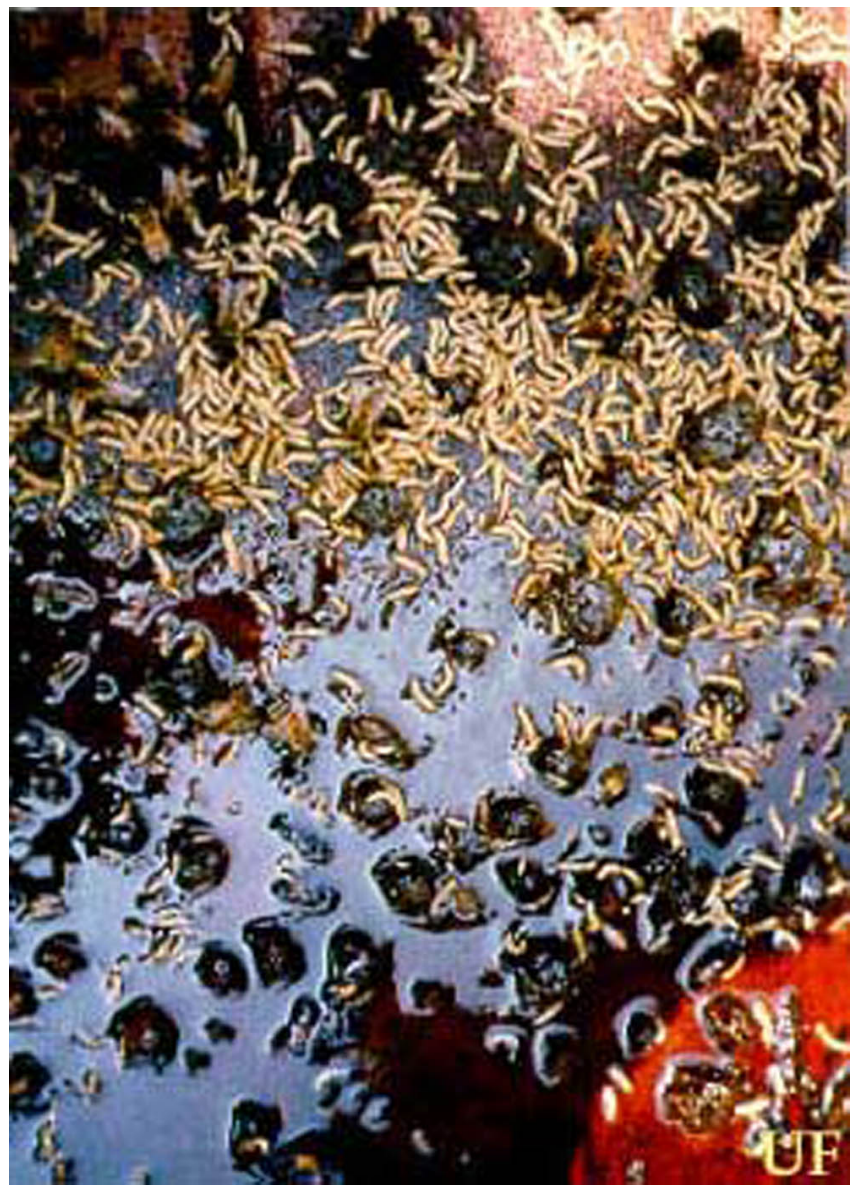

Figure 6. Beetle larvae in fermented honey on the bottom board. Credits: M.T. Sanford, University of Florida

\section{Action Threshold}

Honey bee colonies appear to withstand large populations of adults with impunity. These, however, are capable of laying numerous eggs, which quickly develop into larvae, creating havoc in the honey house and unprotected honey-filled supers. Stacking supers containing larvae on healthy colonies is also reported to cause their collapse. Scrupulous sanitation by extracting honey within a day or two or removal and rendering the cappings will often keep infestations at bay.

Chemical control of beetles is problematic because no action thresholds have been defined. There are two routes to control: 1) in the colony and 2) soil treatment for developing pupae. A Section 18 special exemption for Bayer Bee Strips (CheckMite +) has been authorized by the Environmental Protection Agency (EPA). This is formulated using the active ingredient coumphos (10\%), an organophosphate pesticide impregnated in a plastic strip. Honey supers must be removed before applying this material as a plastic strip stapled onto cardboard inserts. In Florida, it must also be used in accordance with a label and two separate memoranda written to the Florida Department of Agriculture and Consumer Services by EPA dated January 6 and May 28, 1999. The latter increases the treatment window from seven to 45 days and increases the number of strips that can be sold in Florida to 700,000. All the documents must be in the hands of applicator at time of application. For more specific information, contact a beekeeping supply outlet.

\section{A product called GardStar ${ }^{\circledR}(40 \%$ EC) has also} been labeled for treating small hive beetle in the soil. It is formulated as an emulsifiable concentrate containing $40 \%$ permethrin. It can be used any time of year and applied by low-pressure spray equipment. The product is packaged in $4 \mathrm{fl}$. oz. bottles with a 15-mil self-dispensing chamber for easy mixing. Again, it must be used in accordance with the label and can be found in many garden and pest control stores.

\section{Management}

The first line of defense for small hive beetle is sanitation in the bee yard and honey house. Dr. Lundie says that the principal time beekeepers have trouble in South Africa is when combs of honey stand for long periods in the honey house prior to extraction, especially those that contain pollen. Cappings set aside during the extracting process may also become "wormy." Honey left over Porter bee escapes for a period is also at risk. All these lead to infestations because honey bees are not available to remove either larvae or adults from the colony. Thus, Dr. Lundie concludes, "Any factor which so reduces the ratio of the population of a colony of bees to its comb surface that the bees are no longer able to protect this comb surface adequately is a precursor to the ravages of both the wax moths and Aethina tumida."

This is good advice; it already is common beekeeping practice in both Africa and Florida. The bees in Africa, however, are different than those in most of North America. Apis mellifera scutellata, the African honey bee, has radically different behavior 
from that found in the European Apis mellifera bee, managed by the beekeepers of North America. It is already known that African bees in the face of light predation or perturbation readily abscond. In doing so, they leave behind a nest heavily infested with all kinds of possible organisms. Dr. Lundie suggests that this behavior may be a reason why American foulbrood has never taken hold in South Africa. Scavengers like wax moths and A. tumida remove abandoned nests so quickly that the disease reservoir ceases to exist. European honey bees are not as likely to abscond as African bees; they also may not be as hygienic in the nest. Both are reasons that their relatives Africanized bees are thought to be more tolerant of the varroa mite.

Another African honey bee, Apis mellifera capensis, is also affected by the beetle, but appears also to be withstanding its effects. What does inferior hygienic behavior and the lack of a tendency to abscond portend for North American bee colonies invaded by A. tumida? Dr. Lundie provides a hint of this in his publication, saying that when honey bees cannot eject the beetle easily, strong as well as weak colonies may be equally affected. In addition, even in South Africa, at rare times the beetle can heavily affect colonies.

A. tumida is at its most vulnerable when the larvae leave the hive to pupate in the soil, and this probably represents a good starting point for beekeepers to experiment with controlling this insect by cultural means. Perhaps the larvae can be trapped somehow before they reach the soil. Soil conditions also become important; the larvae may not pupate effectively in too dry, sandy or wet conditions. Dr. Lundie reports some indications that larvae infested with a soil-dwelling fungus died. Certain ants or other insects may prey on the larvae. The imported fire ant (Solenopsis invicta) in the southern United States comes to mind as a possibility in some areas.

Dr. Lundie reports that stationary colonies are more vulnerable than those that are moved. Thus, relocating colonies may break the beetle's life cycle, a classic control measure used elsewhere in agriculture. Certainly the bees' self-cleaning behavior itself should be used to the utmost. Colonies will probably vary in the ability to withstand infestation and should be monitored for the ability to do so. As part of this, beekeepers should be very careful not to provide more exposed comb than the bees can adequately cover, or purposefully infest a colony that doesn't already have beetles. The beetle's arrival could signal a paradigm shift in honey bee management. Standard practices like stacking empty or weak colonies on stronger ones, making weak splits, and/or liberally exchanging combs are not good options in beetle control.

Beekeepers should constantly monitor their operations for presence of the beetle. Detection is relatively easy. The larvae can be examined for the six rather large legs on their front end; wax moth larvae have uniformly sized prolegs found in most lepidopterous larvae. In contrast to those of the beetle, wax moth larvae do not usually move toward light, leave a colony nor burrow into the soil. Adult beetles are easy to spot, uniform in color and about one-third the size of an adult worker bee. They rapidly run across the combs and can often be found hiding in places that are not accessible to larger-bodied honey bees. Until more is known about the beetle in a particular area, it should be assumed that it is far more aggressive a scavenger than the wax moth and may overwhelm even strong, healthy colonies.

If $A$. tumida is suspected or detected, the following precautions are suggested:

1. Be scrupulously clean around the honey house. Leave filled supers standing only a short time before extraction. Beetles may rapidly build up in stored honey, especially where honey has been stored over pollen.

2. Be careful stacking infested equipment or extracted supers onto strong colonies.

Beekeepers doing this before the beetle was identified may have inadvertently dealt a deathblow to unifested, healthy colonies by providing space for the beetles to build up that the bees could not protect.

3. Pay close attention when supering colonies, making splits or exchanging combs; all these activities could provide room for the beetle to become established away from the cluster of protective bees. 
4. Monitor colonies for hygienic behavior; are the bees actively attempting to rid themselves of both larval and adult $A$. tumida? If not, replace them.

5. Experiment with traps in an attempt to keep larvae from reaching the soil where they complete their development. Try moving bees from place to place. Adult beetles can fly, but their range is not known with certainty. Some areas may be much more hospitable to beetles due to local soil conditions than others.

Other tidbits of information have been obtained through observation of beetle behavior:

-When the number of small hive beetle larvae reaches a certain level in a colony, honey bee brood rearing stops.

- Adult beetles appear to be eating bee eggs and may even consume their own eggs. Larval cannibalism is also reported.

- Amber light shone on frames at night will cause adult beetles to move and be detected.

- Adult beetles do not get caught on sticky boards, and move quickly across them.

- Adult beetles will lay eggs on fruit, but this does not appear to be their preferred diet.

- Best survey technique for beetles is carefully examining the frass on bottom boards and/or cardboard inserts, with one side removed and the exposed corrugated portion in contact with the bottom board. The beetles apparently are drawn to this material and easily hide in the corrugations. This has now been integrated with use of coumaphos impregnated plastic strips.

- There is no need to consider treating this pest until it has been detected in the apiary. The mood of some beekeepers appears to be one of preventive treatments. This is not warranted.

- Location of major infestations appear to be confined to the southeastern United States coastal plain. It could well be that soil moisture or makeup is optimal in these areas. The beetle may not effectively reproduce in other ecosystems, which are quite different in climate and soil type. A. tumida has been described as a subtropical to tropical organism in much of Africa, but it is reported to also withstand temperate weather conditions in its homeland.

- Freezing honey in the comb appears to kill both beetle and wax moth eggs and larvae.

- Soil conditioning agents may also affect pupation of the beetle. Muriate of potash, sometimes known as 0600 fertilizer, might act as a dehydrating agent, similar to boric acid crystals for roach control in urban environments.

\section{Selected References}

Buys B, Durr HJR, Giliomee JH; Neser S (eds.). A survey of honeybee pests in South Africa. 1975 Entomological Society of Southern Africa: Proceedings of the First Congress of the Entomological Society of Southern Africa, 1974 Stellenbosch 185-189; 9 ref.

Delaplane, K.S. (1999). The Small Hive Beetle (Aethina tumida), Bugwood Publication \#98-0111, Entomology and Forest Resources Information Digital Working Group. (June 1999).

Lundie A.E. The Small Hive Beetle (Aethina tumida). 1940 Union of South Africa Science Bulletin Department of Agriculture and forestry (Entomological Series 3) 220, 30 pp.

Murray A. List of Coleoptera received from Old Calabar, 1867 Annals and Magazine of Natural History (3rd series) 19: 167-179.

Sanford, M.T. (June 1999). APIS: Small Hive Beetle Topics. http://apis.ifas.ufl.edu/threads/smbeetle.htm (June 1999).

Thomas, M. (February 2000). A Honeybee Pest New to Florida and the Western Hemisphere Aethina tumida Murray (Coleoptera: Nitidulidae, June. http://www.doacs.state.fl.us/pi/enpp/ento/ aethinanew.htm (June 1999). 